\title{
Delayed Tooth Replantation after Treatment of Necrotic Periodontal Ligament with Citric Acid
}

\section{Reimplante dentário tardio após tratamento do ligamento periodontal necrótico com ácido cítrico}

Leandro de Carvalho CARDOSO

DDS, MS, PhD - School of Dentistry of Araçatuba - UNESP - Univ Estadual Paulista - Department of Surgery and Integrated Clinics - Araçatuba - SP - Brazil

Eloá Rodrigues LUVIZUTO

DDS, MS, PhD - School of Dentistry of Araçatuba - UNESP - Univ Estadual Paulista - Department of Surgery and Integrated Clinics - Araçatuba - SP - Brazil

Wilson Roberto POI

DDS, MS, PhD - School of Dentistry of Araçatuba - UNESP - Univ Estadual Paulista - Department of Surgery and Integrated Clinics - Araçatuba - SP - Brazil

Sonia Regina PANZARINI

DDS, MS, PhD - School of Dentistry of Araçatuba - UNESP - Univ Estadual Paulista - Department of Surgery and Integrated Clinics - Araçatuba - SP - Brazil

Daniela Naves TRUITE

DDS - School of Dentistry of Araçatuba - UNESP - Univ Estadual Paulista Department of Surgery and Integrated Clinics - Araçatuba - SP - Brazil

Celso Koogi SONODA

DDS, MS, PhD - School of Dentistry of Araçatuba - UNESP - Univ Estadual Paulista - Department of Surgery and Integrated Clinics - Araçatuba - SP - Brazil

Paulo Barbosa Andrade

DDS - School of Dentistry of Araçatuba - UNESP - Univ Estadual Paulista Department of Surgery and Integrated Clinics - Araçatuba - SP - Brazil

\begin{abstract}
Objective: to evaluated the effect of treating root-adhered necrotic periodontal ligament (PDL) with citric acid on the healing process in delayed rat tooth replantation. Material and Methods: Forty Wistar rats, assigned to 4 groups $(\mathrm{n}=10)$, had their upper right incisor extracted and kept dry on a workbench. For Group I (control), the teeth were replanted after a 5 min extra-alveolar time. For the other groups, replantation was done after $60 \mathrm{~min}$. In Group II, the root canals were filled with a calcium hydroxide-based paste and the teeth were replanted with no root surface treatment. In Group III, the teeth were immersed in citric acid ( $\mathrm{pH} 1)$ for $3 \mathrm{~min}$, the canals were filled with calcium hydroxide and the teeth were replanted. In Group IV, instead of the immersion, the roots were scrubbed with gauze soaked in citric acid and the teeth were replanted. The animals were sacrificed 60 days postoperatively. Results: Regarding replacement resorption, there was statistically significant difference $(p<0.05)$ between the control group and the other three groups. No statistically significant difference $(p>0.05)$ was found among the groups regarding the areas of inflammatory resorption. There was also a statistically significant difference $(p<0.05)$ between the control group and Group IV regarding ankylosis. The control group showed the least replacement resorption percent means compared to the other groups $(\mathrm{p}<0.05)$. The root structure was more affected by replacement resorption and ankylosis in Group IV compared to the Groups II and III, but this difference was not significant statistically $(p>0.05)$. Conclusion: the treatment of root surface-adhered necrotic periodontal ligament with citric acid was not able to prevent the occurrence of ankylosis, root resorption and inflammatory resorption in delayed rat tooth replantation.
\end{abstract}

\section{KEY-WORDS}

Avulsion; Tooth replantation; Rats; Trauma; Periodontal ligament; Root surface treatment.

\section{Resumo}

Objetivo: avaliar o efeito do ácido cítrico no ligamento periodontal cementário necrótico no processo de reparo do reimplante dentário tardio em rato. Material e Método: Quarenta ratos Wistar após a extração do incisivo superior direito foram divididos em 4 grupos $(\mathrm{n}=10)$. No Grupo I (controle), os dentes foram reimplantados após 5 min extralveolar. Nos outros grupos o reimplante foi realizado após 60 min. No Grupo II, os canais foram obturados com pasta hidróxido de cálcio e os dentes foram reimplantados sem tratamento da superfície radicular. No Grupo III, os dentes foram imersos em ácido cítrico (pH1) por $3 \mathrm{~min}$, os canais foram obturados com pasta de hidróxido de cálcio e reimplantados. No Grupo IV, a superfície radicular foi friccionada com gaze embebida em ácido cítrico e os dentes reimplandos. Os aminais sofreram eutanásia 60 dias após o reimplante. Resultados: Quanto à reabsorção por substituição houve diferença estatisticamente significativa $(p<0,05)$ entre o grupo controle e os outros três grupos. Não foi observada diferença estatisticamente significante $(p>0,05)$ entre os grupos com relação à reabsorção inflamatória. Houve também uma diferença estatisticamente significante $(p<0,05)$ entre o grupo controle e do Grupo IV quanto a anquilose. O grupo controle apresentou menor reabsorção por substituição em comparação com os outros grupos $(\mathrm{p}<0,05)$. A estrutura radicular foi mais comprometida pela reabsorção por substituição e anquilose no Grupo IV quando comparado aos grupos II e III, porém sem significância estatística $(\mathrm{p}>0.05)$. Conclusão: o tratamento do ligamento periodontal cementário com ácido citrico não previne a ocorrência de anquilose e reabsorção inflamatória em reimplante dentário tardio em rato.

\section{PalaVRas-chave}

Avulsão; Reimplante dentário; Rato; Trauma; Ligamento periodontal; Tratamento de superfície. 


\section{INTRODUCTION}

It is generally well accepted that the ideal treatment for an avulsed permanent tooth is its immediate replantation into the socket, which can yield, at least temporarily, the reestablishment of esthetics and function [1]. However, clinical experience has shown that most avulsed teeth are replanted after an extra-alveolar time of over 60 min. The main possible causes for this statistics are factors associated to the accident itself, like extensive life-threatening traumas or damaged receptor sites, as well as lack of knowledge or confidence about replantation procedures [2]. Therefore, in spite of having a recognizably favorable prognosis, in practice, immediate replantation (within 5 to $20 \mathrm{~min}$ ) is performed only in a few situations [3-6].

The survival rate of a replanted tooth is associated with periodontal ligament (PDL) degeneration, which in turn is directly related to the handling or trauma of the root, the extra-alveolar time, the storage medium in which the tooth is maintained until replantation, and the type of resorption developed during the healing process $[5,6]$.

Several treatments have been proposed for delayed tooth replantation. Acidic solutions, such as citric acid, phosphoric acid, hydrochloric acid and ascorbic acid have been employed for root surface treatment after removal of periodontal ligament [7-12]. The goals of using acidic solutions include $\mathrm{pH}$ neutralization (if sodium hypochlorite is used for chemical removal of periodontal ligament), reattachment of collagen fibers to cementum surface [7-13] and elimination of bacterial endotoxin [14].

Two previous studies $[15,16]$ have described a clinical protocol for avulsed teeth that had an extraalveolar time of over $60 \mathrm{~min}$, which indicates the direct application of citric acid to the necrotic periodontal ligament for $5 \mathrm{~min}$ as a viable root surface treatment option. It is unknown, however, whether necrotic periodontal ligament remnants treated with citric acid is biologically compatible because most studies focused on the repair process have employed citric acid after complete removal of necrotic periodontal ligament remnants by mechanical or chemical means $[4,17]$.

Therefore, the purpose of this study was to evaluate histomorphometrically the effect of treating root-adhered necrotic periodontal ligament with citric acid on the healing process in delayed rat tooth replantation.

\section{Materials and Methods}

\section{Ethics and Study design}

The research proposal was submitted to review by the Ethics in Animal Experimentation Committee of the School of Dentistry of Araçatuba (São Paulo State University, Brazil) and the study designed was approved.

Forty male Wistar rats (Rattus norvegicus albinus) weighing 250 to $300 \mathrm{~g}$ were used in this study. After tooth extraction, the animals were assigned to 4 groups, as follows: GROUP I: The extracted teeth were kept dry on a workbench for $5 \mathrm{~min}$ and thereafter replanted into their sockets; GROUP II: The extracted teeth were benchdried for $60 \mathrm{~min}$. Afterwards, the dental papilla and the enamel organ were sectioned with a \#15 scalpel blade (Embramac Exp. e Imp., Campinas, SP, Brazil) and pulps were extirpated through a retrograde via using a slightly curved \#35 Hedstrom file (Sybron Kerr, Romulus, MI, USA). The canals were irrigated with saline (Ariston Ind. Quims. e Farms. Ltda, São Paulo, SP, Brasil), aspirated, dried with absorbing paper points (Dentsply Ind. e Com. Ltda., Petrópolis, RJ, Brazil) and filled with a calcium hydroxide (Calcium Hydroxid für Analyse, Criedel, De Rainag Seelge, Hanover) and propyleneglycol paste. The paste was packed in a cartridge syringe with a long needle and inserted into the canals through a retrograde via. After this, the sockets were irrigated with saline and the teeth replanted; GROUP III: The extracted teeth were treated as described for Group II (60-min workbench time and pulpectomy), and then immersed for $3 \mathrm{~min}$ in citric acid (pH 1) and rinsed with $20 \mathrm{~mL}$ saline using a Luer syringe with 25/4 needle for $2 \mathrm{~min}$. Thereafter, root canal treatment and replantation procedures were performed as described for Group II; GROUP IV: The same procedures as described for Group III, except for the fact that, instead of acid immersion, the root surfaces were scrubbed with gauze soaked in the same citric acid solution for $3 \mathrm{~min}$.

After replantation no type of contention was made. All animals received a single intramuscular injection of penicillin $\mathrm{G}$ benzathine 20,000 IU (Fontoura Wyeth S.A., São Paulo, SP, Brazil). The animals were sacrificed by anesthetic overdose 60 days postoperatively.

The blocks containing the replanted teeth were removed and submitted to histological processing. The specimens were fixed in $10 \%$ formalin for $24 \mathrm{~h}$, decalcified in a $4.13 \%$ EDTA, pH 7.0 and embedded in paraffin. Semi-serial $6-\mu \mathrm{m}$-thick sections were cut longitudinally to root surface and only those from the middle third were considered for analysis. The sections were stained with hematoxylin and eosin for histomorphometric analysis. 


\section{Histomorphometric Analysis}

For histomorphometric analysis, the middle thirds of the roots were measured considering the total dentin and cementum areas, inflammatory resorption areas, replacement resorption areas and ankylosis perimeter. The collected data were entered on Microsoft Office Excel 2003 software (Microsoft Corporation, Redmond, WA, USA) for statistical analysis.

\section{Statistical Analysis}

Because the quantified histomorphometric parameters had great variability, data were analyzed using nonparametric statistical tests. The Kruskal-Wallis test was used to compare the data by analysis of variance and, when statistically significant differences were detected, the Mann-Whitney U-test was used for individual comparisons. Significance level was set at 5\% $(p<0.05)$.

\section{Results}

The qualitative results were described from the examination of the middle third of the roots considering the following structures: dentin, cementum, periodontal ligament and alveolar bone.

Group I (control) was characterized by the integrity of cementum and dentin and by the maintenance of periodontal ligament fibers (Figure 1), which were well organized and oriented parallel to root surface. The presence of blood vessels was also observed (Figure 2).

In Group II (delayed replantation with no root surface treatment), all specimens were affected by root resorption (with predominance of replacement resorption) and presented a fibrous connective tissue (Figure 3). Only one specimen showed inflammatory resorption and other three specimens exhibited signs of ankylosis. In this group, the periodontal ligament space was visible in only few root surface areas. In most cases, dentin was replaced by bone tissue (Figure 4).

In Group III (immersion in citric acid), although all specimens were affected by root resorption, the root structure was significantly less compromised than in Groups II and IV (Figure 5). In five specimens, the periodontal ligament space was occupied by a connective tissue with several fibroblasts and collagen fibers, which were disorganized and obliquely arranged. Intact cementum areas were also found in some specimens, but these areas were less extensive than in the control group (Figure 6).

Group IV (scrubbing with citric acid) was the most affected by root resorption (Figure 7). In most cases, the periodontal ligament was replaced by bone, which caused narrowing of the periodontal ligament space and characterized the occurrence of ankylosis (Figure 8). Only one specimen had the periodontal ligament space filled with a fibrous connective tissue (Figure 8).

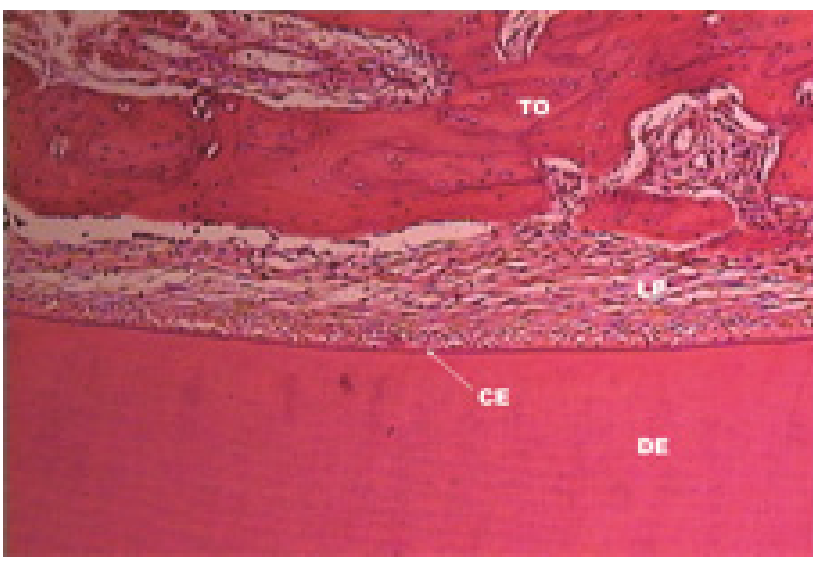

Figure 1 - (Group I) Intact cementum and dentin and preserved periodontal ligament. Hematoxylin-eosin (original magnification X40).

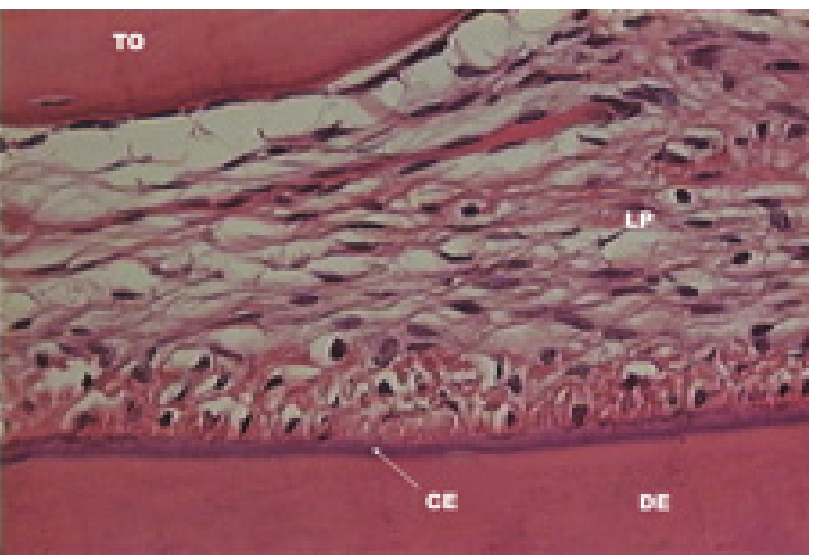

Figure 2 - (Group I) Intact cementum and dentin and well organized periodontal ligament fibers. Hematoxylin-eosin (original magnification X163).

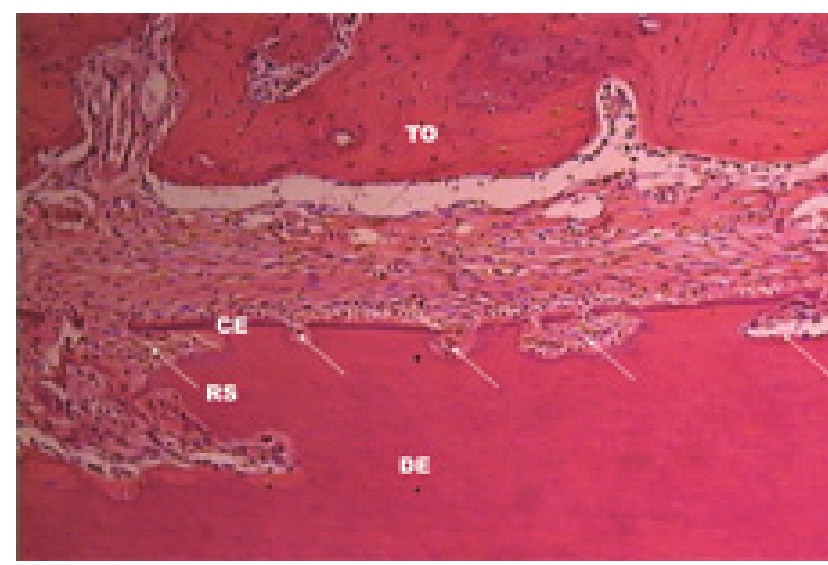

Figure 3 - (Group II) Active replacement resorption, involving the cementum and larger dentin areas. Hematoxylin-eosin (original magnification X40). 


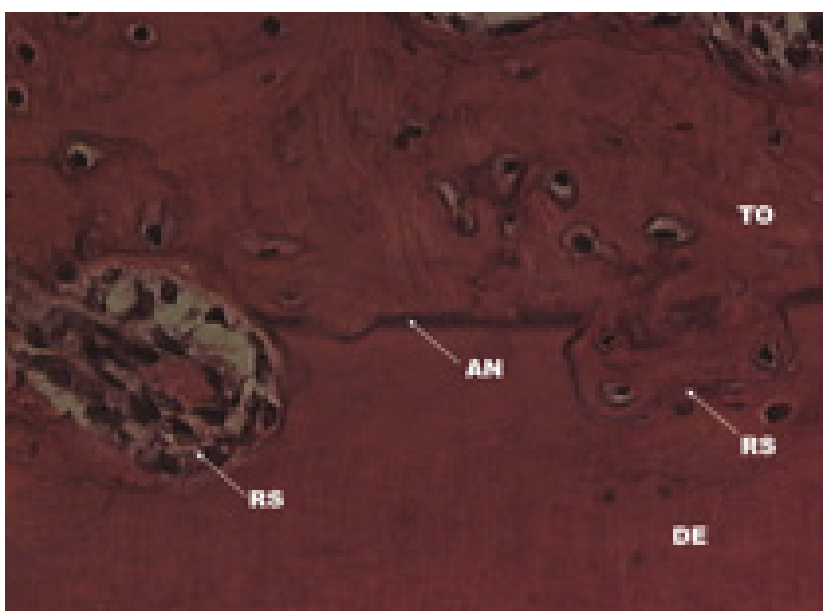

Figure 4 - (Group II) Presence of ankylosis and replacement resorption. Hematoxylin-eosin (original magnification X163).

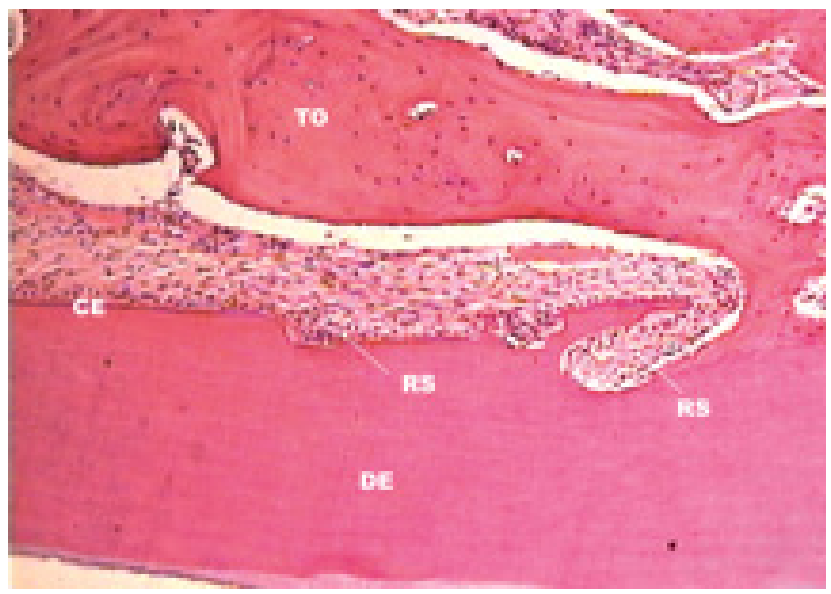

Figure 5 - (Group III) Active replacement root resorption involving cementum and dentin. Hematoxylin-eosin (original magnification X163).

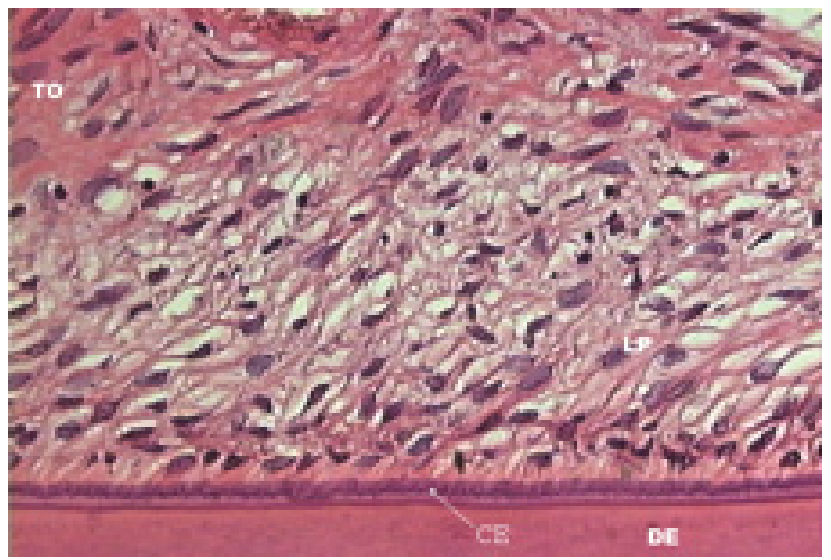

Figure 6 - (Group III) Closer view of intact cementum and dentin surface. Disorganized and obliquely arranged periodontal ligament fibers. Presence of osteoid tissue. Hematoxylin-eosin (original magnification X163).

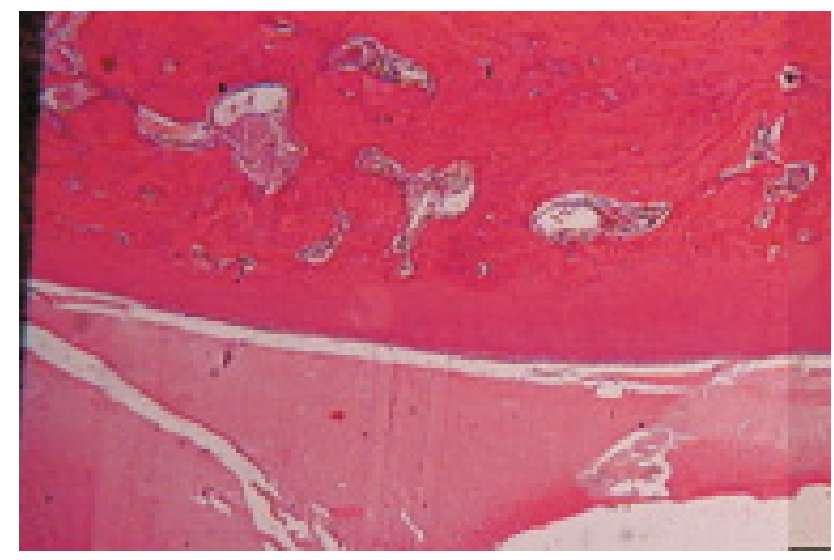

Figure 7 - (Group IV) Replacement resorption, showing cementum and dentin replacement by bone tissue. Hematoxylin-eosin (original magnification X40).

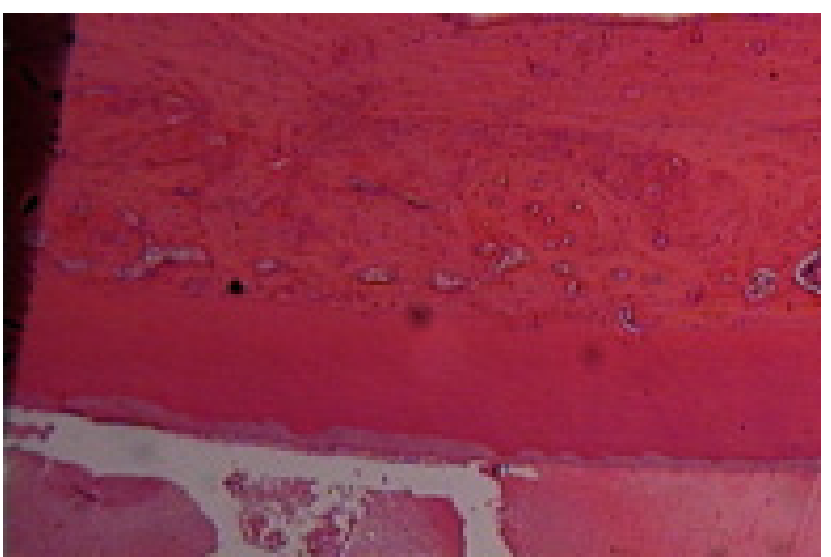

Figure 8 - (Group IV) Replacement resorption and ankylosed areas. Hematoxylin-eosin (original magnification X40).

Figure 9 presents the percent means of areas of replacement resorption, ankylosis and inflammatory resorption. Group I had low percent means of root resorption and ankylosis compared to the other three groups. Group III presented slightly lower values of replacement resorption than Groups II and IV. Group IV (scrubbing with citric acid) had the highest percent means of ankylosis.

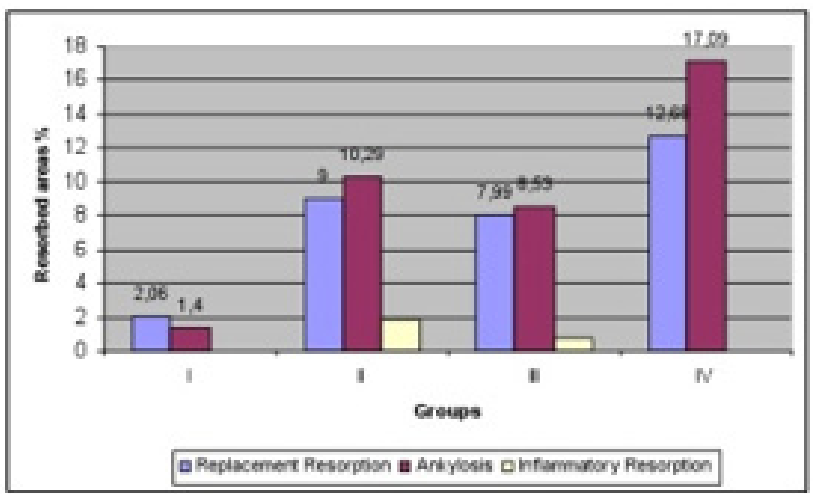

Figure 9 - Ankylosis, replacement resorption and inflammatory resorption percent means for each group. 
No statistically significant difference $(\mathrm{p}>0.05)$ was found among the groups regarding the areas of inflammatory resorption. Regarding replacement resorption, there was statistically significant difference $(\mathrm{p}<0.05)$ between the control group and the other three groups. Regarding the occurrence of ankylosis, Group I (control) differed significantly only from Group IV $(\mathrm{p}<0.05)($ Table 1).

\section{Table 1 - Results of Mann-Whitney U-test FOR GROUP COMPARISON RELATIVE TO ANKYLOSIS, REPLACEMENT RESORPTION AND INFLAMMATORY RESORPTION}

* = statistically significant $(p<0.05)$.

\begin{tabular}{c|c|c|c|c|c|c}
\hline \multirow{2}{*}{$\begin{array}{c}\text { Group } \\
\text { interactions }\end{array}$} & \multicolumn{2}{|c|}{$\begin{array}{c}\text { Replacement } \\
\text { Resorption }\end{array}$} & \multicolumn{2}{|c|}{ Ankylosis } & \multicolumn{2}{c}{$\begin{array}{c}\text { Inflammatory } \\
\text { Resorption }\end{array}$} \\
\cline { 2 - 7 } & $\mathbf{Z}$ & $\mathbf{p}$ & $\mathbf{Z}$ & $\mathbf{p}$ & $\mathbf{Z}$ & $\mathbf{p}$ \\
\hline (I) $\mathbf{x}$ (II) & 2.818 & $0.005^{*}$ & 1.223 & 0.221 & 1.134 & 0.257 \\
(I) $\mathbf{x}$ (III) & 2.592 & $0.010^{*}$ & 1.351 & 0.177 & 1.546 & 0.122 \\
(I) $\mathbf{x}$ (IV) & 2.374 & $0.018^{*}$ & 2.275 & $0.023^{*}$ & 0.000 & 1.000 \\
(II) $\mathbf{x}$ (III) & 0.694 & 0.487 & 0.251 & 0.802 & 0.331 & 0.741 \\
(II) $\mathbf{x}$ (IV) & 0.319 & 0.749 & 0.465 & 0.642 & 1.000 & 0.317 \\
(III) $\mathbf{x}$ (IV) & 0.463 & 0.643 & 1.076 & 0.282 & 1.369 & 0.171 \\
& & & & & & \\
\hline
\end{tabular}

\section{Discussion}

Pulp necrosis and periodontal ligament damage are the main complications in tooth replantation. The negative effects of pulp infection may be avoided or attenuated by the endodontic treatment of the replanted tooth $[15,16,18]$.

The direct injury due to the rupture of periodontal ligament fibers during avulsion cannot be avoided. However, the further complications arising from PDL damage caused by the extra-alveolar time can be attenuated $[15,16,18]$ by either immediate replantation $[19,20]$ or maintenance of the avulsed tooth in adequate storage media, such as Hank's balanced salt solution, Viaspan, milk, saline and saliva, to preserve PDL cell vitality $[15,16,18]$. When the periodontal ligament cells are not viable, the treatment goal should be to minimize the effects of the necrotic periodontal ligament remnants $[15,16,18]$, in order to delay the start of root resorption and increase the survival rate of the replanted tooth $[15,16,18]$.

Several authors $[1,2,13,17]$ have recommended the removal of the devitalized periodontal ligament, while others $[15,16,18]$ have suggested that chemical substances may be used to treat the devitalized PDL remnants that remain adhered to root surface with no need of PDL removal.

Most studies referring to the use of acidic substances (hydrochloric, citric, phosphoric and ascorbic acids) in cases of delayed tooth replantation have investigated the repair process after complete PDL removal by mechanical or chemical means and/or the treatment of root surface with the abovementioned acid solutions [7-12]. However, the biocompatibility of the necrotic periodontal ligament treated with citric acid is unknown. This was the rationale for performing the present study.

Trope $[15,16]$ have described a treatment protocol for delayed tooth replantation according to which citric acid is directly applied to the root surfaceadhered necrotic periodontal ligament for $5 \mathrm{~min}$ in avulsed teeth with extra-alveolar times longer than $60 \mathrm{~min}$. However, the scope of both studies was not to assess the effects of citric acid on the periodontal ligament.

An experimental study of maxillary incisors in dogs was carried out to test the hypothesis that demineralization of denuded root surfaces by citric acid for 3 min might improve the periodontal regeneration rate after replantation of traumatically avulsed and dried teeth7. These preliminary observations indicate that the frequency of adverse healing results (root resorption and ankylosis) after delayed replantation can be reduced by removing nonvital soft tissue remnants, demineralizing the root surface and preventing mechanical trauma to root surface and alveolar walls during replantation or postoperatively. Based on the observations of the use of citric acid in cases of bone losses resulting from periodontal disease, Van Hassel et al. [21] reported that when applied to denuded root surfaces for 3 min, citric acid was able to yield demineralization to a depth of $5 \mu \mathrm{m}$. Therefore, the effect of citric acid when placed in direct contact with root surfaces free of periodontal ligament remnants is known. This limit of penetration was taken into account for choosing the length of citric acid application ( $3 \mathrm{~min}$ ) used in the present investigation.

In the present study, neither immersion nor scrubbing with citric acid (pH 1) for 3 min (Groups III and IV) was sufficient to provide complete removal of devitalized periodontal ligament remnants, perhaps promoting PDL conditioning. Immersion in citric acid (Group III) did not provide satisfactory healing results in view that there was no significant difference in the 
areas of ankylosis and replacement/inflammatory resorption compared to Group II (delayed replantation without root surface treatment).

Although there was no statistically significant difference between citric acid immersion (Group III) and citric acid scrubbing (Group IV) referring to the percent means of replacement resorption and ankylosis, the values were higher in the acidscrubbed group. This can possibly be explained by the mechanical trauma caused by root surface scrubbing with gauze, which might have removed part of the periodontal ligament fibers and accelerated the processes of ankylosis and root resorption.

The protocol followed in the present study for bacterial endotoxin control, comprising root canal biomechanical instrumentation, placement of a calcium hydroxide-based intracanal dressing [4,22] and systemic antibiotic therapy [23], was effective in controlling the occurrence of inflammatory resorption; the groups did not differ significantly to each other and the results were within the range of values reported in a recent study [20].

The good results of Group I (control) underscore the need for spreading the knowledge of tooth replantation by providing the general population with basic information on replantation procedures and emphasizing the importance of immediate replantation to increase the survival rate of replanted teeth. The existence of several areas of replacement resorption in most specimens of Groups II, III and IV indicates that the progress of the healing process might result in complete root resorption of the replanted tooth.

The choice for certain root-surface treatment modalities may lead some specimens to be less compromised than others, which raises the possibility of a higher survival rate of replanted teeth. This confirms the importance of undertaking studies to investigate root surface treatment. The use of citric acid for longer times or with different $\mathrm{pHs}$, whether associated or not with other forms of treatment should be investigated.

Even though there is no effective method for controlling replacement resorption16, tooth replantation should always be the treatment of choice for exarticulated permanent teeth. Replantation reestablishes temporarily the function and esthetics and provides psychological comfort to the patient, in addition to preserving the amount and quality of alveolar bone, thus permitting later insertion of a metallic implant, if this should be necessary.

\section{Conclusion}

The treatment of root surface-adhered necrotic periodontal ligament with citric acid was not able to prevent the occurrence of ankylosis, root resorption and inflammatory resorption in delayed rat tooth replantation.

\section{References}

1. Andreasen JO, Andreasen FM. Avulsions. In: Andreasen JO, Andreasen FM, Lars Andersson, editors. Textbook and color atlas of traumatic injuries to the teeth. 4 th ed. Munksgaard Publishers: Copenhagen: 2006. p. 383-425.

2. Poi WR, Salineiro SL, Miziara FV, Miziara EV. Education as a means of enhancing the prognosis of tooth replantation. Rev Assoc Paul Cir Dent 1999;53:474-9.

3. Löe H, Waerhaug J. Experimental replantation of teeth in dogs and monkeys. Arch Oral Biol 1961;3:176-84.

4. Andreasen JO. Effect of extra-socket period and storage media upon periodontal and pulpal healing after replantation of mature permanent incisors in monkeys. Int J Oral Surg 1981;10:43-53.

5. Andreasen JO, Borum MK, Jacobsen HL, Andreasen FM. Replantation of 400 avulsed permanent incisors 4. Factors related to periodontal ligament healing. Endod Dent Traumatol 1995;11:76-89.

6. Andreasen JO, Kristerson L. The effect of limited drying or removal of the periodontal ligament. Periodontal healing after replantation of mature permanent incisors in monkeys. Acta Odontol Scand 1981;39:1-13.

7. Klinge B, Nilvéus R, Selvig, KA. The effect of citric acid on repair after delayed tooth replantation in dogs. Acta Odontol Scand 1984;42:351-9.

8. Nyman S, Houston F, Sarhed G, Lindhe J, Karring T. Healing following replantation of teeth subjected to root planing and citric acid treatment. J Clin Periodontol 1985;12:294-305.

9. Skoglund A. A study on citric acid as a proposed replacement resorption inhibitor. Swed Dent J 1991;15:161-9.

10. Zervas P, Lambrianidis T, Karabouta-Vulgaropoulou I. The effect of citric acid treatment on periodontal healing after replantation of permanent teeth. Int Endod J 1991;24:31725 .

11. Nordenram A, Bang G, Anneroth G. A histopathologic study of replanted teeth with superficially demineralized root surfaces in Java monkeys. Scand J Dent Res 1973;81:294302.

12. Panzarini SR, Perri de Carvalho AC, Poi WR, Sonoda CK. Use of vitamin C in delayed tooth replantation. Braz Dent J. 2005; 16:17-22.

13. Ehnevid H, Lindskog S, Jansson L, Blomlölf L. Tissue formation on cementum surfaces in vivo. Swed Dent J. 1993; 17:1-8.

14. Polson AM, Proye MP. Effect of root surface alterations on periodontal healing. II. Citric acid treatment of the denuded 
root. J Clin Periodontol. 1982;9:441-54.

15. Trope M. Clinical management of the avulsed tooth. Dent Clin North Am. 1995;39:93-112.

16. Trope M. Clinical management of the avulsed tooth: present strategies and future directions. Dent Traumatol. 2002;18:111 .

17. Lindskog S, Pierce AM, Blomlöf L, Hammarström L. The role of the necrotic periodontal membrane in cementum resorption and ankylosis. Endod Dent Traumatol. 1985;1:96101.

18. Lee JY, Vann WF Jr, Sigurdsson A. Management of avulsed permanent incisors: a decision analysis based on changing concepts. Pediatr Dent. 2001;23:357-60.

19. Hammarström L, Blomlöf L, Lindskog S. Dynamics of dentosocket ankylosis and associated root resorption. Endod Dent Traumatol. 1989;5:163-75.

20. Lam K, Sae-Lim V. The effect of Emdogain gel on periodontal healing in replanted monkeys' teeth. Oral Surg Oral Med Oral Pathol Oral Radiol Endod. 2004;97:100-7.

21. Van Hassel HJ, Oswald RJ, Harrington GW. Replantation 2.
The role of periodontal ligament. J Endod. 1980;6:506-8.

22. Lengheden A, Blomlöf L, Lindskog S. Effect of immediate calcium hydroxide treatment and permanent root-filling on periodontal healing in contaminated replanted teeth. Scand J Dent Res. 1991;99:139-46.

23. Hammarström L, Blomlöf L, Feiglin B, Andersson L, Lindskog S. Replantation of teeth and antibiotic treatment. Endod Dent Traumatol. 1986;2:51-7.

Received: 2012 Nov. 07 Accepted: 2013 Jan. 24

Corresponding author:

Profa. Sônia Regina Panzarini, Rua José Bonifácio 1193, Vila Mendonça, Araçatuba, SP, Brasil. Tel: +55-18-36363201 cel: +55-18-97951830. E-mail: panzarin@foa.unesp.br 